\title{
PENGARUH STRATEGI PEMBELAJARAN KOOPERATIF TIPE STUDENT TEAMS ACHIEVEMENT DIVISION DAN GAYA BERPIKIR TERHADAP HASIL BELAJAR MATEMATIKA
}

\author{
Elfrida Lubis, Sahat Siagian, Mukhtar \\ Sekolah Menengah Kejuruan Negeri 1 Lubuk Pakam, Kabupaten Deli Serdang \\ elfrida_lubis@gmail.com
}

\begin{abstract}
Abstrak: Penelitian ini bertujuan untuk mengetahui perbedaan hasil belajar matematika antara siswa yang diajar dengan strategi pembelajaran kooperatif STAD dan siswa yang diajar dengan strategi pembelajaran ekspositori, mengetahui perbedaan hasil belajar matematika antara siswa dengan gaya berpikir sekuensial abstrak dan siswa dengan gaya berpikir sekuensial konkret, mengetahui apakah ada interaksi antara strategi pembelajaran dengan gaya berpikir dalam mempengaruhi hasil belajar matematika. Hasil pengujian hipotesis menunjukkan bahwa siswa yang diajar dengan menggunakan strategi pembelajaran kooperatif STAD memiliki hasil belajar matematika yang lebih tinggi dibandingkan dengan siswa yang diajar dengan menggunakan strategi pembelajaran ekspositori. Siswa yang memiliki gaya berpikir sekuensial abstrak memiliki hasil belajar matematika yang lebih tinggi dibandingkan dengan siswa yang memiliki gaya berpikir sekuensial konkret dan terdapat interaksi antara strategi pembelajaran dengan gaya berpikir terhadap hasil belajar matematika siswa.
\end{abstract}

Kata Kunci: strategi kooperatif STAD, gaya berpikir, matematika.

Abstract: This study aims to determine the differences in mathematics learning outcomes between students taught with the STAD cooperative learning strategy and students taught with expository learning strategies, find out the differences in mathematics learning outcomes between students with abstract sequential thinking styles and students with concrete sequential thinking styles, knowing is there an interaction between learning strategies with thinking styles in influencing mathematics learning outcomes. The results of hypothesis testing show that students who are taught using STAD cooperative learning strategies have higher mathematics learning outcomes compared to students who are taught using expository learning strategies. Students who have abstract sequential thinking styles have higher mathematics learning outcomes compared to students who have concrete sequential thinking styles and there is an interaction between learning strategies and thinking styles towards students' mathematics learning outcomes.

Keywords: STAD cooperative strategy, thinking style, mathematics.

\section{PENDAHULUAN}

Pada hakikatnya belajar adalah proses perubahan perilaku karena pengalaman dan latihan, dimana tujuan kegiatan adalah perubahan tingkah laku yang menyangkut pengetahuan, keterampilan maupun sikap, bahkan meliputi segenap aspek organisme atau pribadi. Mulyati (2005:5) menjelaskan bahwa belajar adalah merupakan suatu usaha sadar individu untuk mencapai tujuan peningkatan diri melalui latihan- latihan dan pengulanganpengulangan dan perubahan yang terjadi bukan karena peristiwa kebetulan. Winkel (1991:102) belajar adalah suatu aktivitas mental/fisik yang berlangsung dalam interaksi aktif dengan lingkungan yang menghasilkan perubahan- perubahan dalam pengetahuan, pemahaman, keterampilan dan nilai sikap.Perubahan itu bersifat secara relative konstan dan berbekas.Lebih lanjut Hilgard dalam Sanjaya (2009:112 ) : "belajar adalah proses dimana suatu perilaku muncul atau berubah karena adanya respons terhadap suatu situasi".

Hasil belajar adalah kemampuan yang diperoleh dari proses atau kegiatan belajar yang dapat berupa pengetahuan, sikap, keterampilan maupun kreativitasnya. Pengetahuan yang dimaksud adalah berupa fakta,istilah dan prinsip-prinsip, sikap yang dimaksud adalah perhatian,penghargaan, nilai, perasaan, dan emosi, sedangkan keterampilan maupun kreativitas yang dimaksud adalah berupa 
keterampilan dan kreativitas dalam memecahkan masalah. Menurut Arikunto (1999:102) hasil belajar merupakan suatu hasil yang diperlukan siswa dalam mengikuti pelajaran yang dilakukan oleh guru. Hasil belajar ini dikemukakan dalam bentuk angka, huruf, atau kata-kata " baik, sedang, kurang, dan sebagainya". Untuk mencapai hasil belajar yang baik , siswa harus mengembangkan diri menjadi siswa yang baik.

Menurut Benjamin S. Bloom (1986:18) tiga ranah hasil belajar,yaitu: (1) kognitif, (2) afektif dan (3) psikomotorik. Ranah kognitif berkenaan dengan hasil belajar intelektual yang terdiri dari enam aspek, yakni : pengetahuan, pemahaman, aplikasi, analisis, sintesis, dan evaluasi.

Dari pernyataan di atas dapat dikatakan bahwa pencapaian hasil belajar dapat dilihat dari pencapaian bentuk perubahan perilaku yang cenderung menetap dari ranah kognitif, afektif dan psikomotorik dari proses belajar yang dilakukan dalam waktu tertentu, tetapi dari ketiga ranah tersebut yang menjadi objek penilaian untuk hasil belajar, ranah kognitiflah yang paling banyak dinilai karena tujuan utama penilaian adalah mengukur kemampuan para siswa dalam menguasi bahan pelajaran.

Hudojo (1998:3) mengemukakan bahwa matematika berkenaan dengan ide-ide (gagasan-gagasan), struktur-struktur, dan hubugan-hubungan yang diatur secara logik sehingga matematika berkenaan dengan konsep-konsep yang abstrak.

Matematika merupakan ilmu pengetahuan yang memiliki cakupan objek yang sangat luas dan kompleks, mencakup konsep, fakta, skill dan prinsip, transfer belajar,kemampuan memecahkan masalah, kemampuan berpikir kritis dan kemampuan lain sebagainya. Matematika sangat dibutuhkan dalam kebutuhan belajar karena mampu untuk membantu seseorang dalam memecahkan berbagai persoalan yang dihadapinya, menggunakan pola pikir yang sistimatis dan terstruktur (rasional), cermat, jelas dan akurat. Kemampuan untuk menciptakan gagasangagasan dan alternative pemecahan masalah secara rasional ini dapat dimiliki oleh siswa dengan kemampuan dan keterampilan matematika yang memadai guna memperoleh hasil belajar matematika yang optimal. Dalam pelajaran matematika, seorang siswa tersebut dapat dengan mudah memecahkan soal-soal matematika yang berkaitan dengan bahan yang diajarkan. Menurut (Hudoyo,1998:102) siswa yang berhasil dalam belajar matematika akan dapat mendemonstrasikan pengetahuan, pengalaman dan keterampilannya dalam menjawab berbagai persoalan matematika.

Berdasarkan uraian di atas dapat disimpulkan bahwa hasil belajar matematika merupakan tingkah laku atau kemampuan dalam diri siswa berupa pengetahuan yang meliputi penguasaan konsep matematika, sikap dan keterampilan. Hasil belajar ini diperoleh siswa setelah mengikuti serangkaian kegiatan pembelajaran dari setiap mata pelajaran yang dikenai perlakuan. Dalam penelitian ini, mata pelajaran yang dikenai perlakuan adalah mata pelajaran matematika dengan materi pelajaran Barisan dan Deret, sedang hasil belajar siswa dibatasi pada ranah kognitif dengan indikator pengetahuan, pemahaman, penerapan, analisis, sintesis dan evaluasi.

Dalam dunia pendidikan, strategi diartikan sebagai perencanaan yang berisi tentang rangkaian kegiatan yang didesain untuk mencapai tujuan pendidikan tertentu (Sanjaya, 2009:126).Wena (2009:21) menjelaskan strategi berarti cara dan seni untuk menggunakan semua sumber belajar untuk mencapai tujuan tertentu.

Dari beberapa definisi di atas dapat disimpulkan strategi pembelajaran merupakan suatu rencana tindakan (rangkaian kegiatan) yang termasuk juga penggunaan metode dan pemanfaatan berbagai sumber daya/kekuatan dalam pembelajaran agar tujuan pembelajaran dapat tercapai dengan baik. Ini berarti penyusunan suatu strategi baru sampai pada proses penyusunan rencana kerja belum sampai pada tindakan, strategi disusun untuk mencapai tujuan tertentu sehingga penyusunan langkahlangkah pembelajaran, pemanfaatan berbagai fasilitas dan sumber belajar semuanya diarahkan dalam upaya pencapaian tujuan. Dick dan Carey (2005:89) menjelaskan bahwa strategi pembelajaran menggambarkan komponen-komponen umum dari suatu set bahan pembelajaran yang digunakan untuk menghasilkan belajar siswa.

Berbagai strategi pembelajaran telah diperkenalkan oleh para ahli dalam rangka mencapai tujuan pembelajaran yang disesuaikan dengan karakteristik siswa dan karakteristik mata pelajaran. Strategi pembelajaran yang dapat digunakan menurut Sanjaya (2009:299) antara lain: strategi pembelajaran kooperatif, strategi pembelajaran inquiry, strategi pembelajaran ekspositori. Dalam penelitian ini 
strategi yang digunakan adalah strategi pembelajaran kooperatif dan strategi pembelajaran ekspositori.

Tom V. Savage (dalam Rusman, 2011:203) mengemukakan bahwa pembelajaran kooperatif adalah suatu pendekatan yang menekankan kerjasama dalam kelompok. Gage dan Berliner (1998:59) menjelaskan bahwa dalam pembelajaran kooperatif membuat siswa bekerjasama dalam kelompok, meningkatkan partisipasi siswa dalam proses belajar, meningkatkan kemampuan berbicara siswa dan meningkatkan pencapaian akademis.

Slavin (dalam Isjoni, 2009:15) menyatakan bahwa pembelajaran kooperatif adalah suatu model pembelajaran dimana siswa belajar dan bekerja sama dalam kelompokkelompok kecil secara kolaboratif yang anggotanya terdiri dari 4-6 orang dengan struktur kelompok heterogen. Jadi dalam pembelajaran kooperatif ini, siswa bekerja sama dengan kelompoknya untuk menyelesaikan suatu permasalahan, dengan begitu siswa akan bertanggung jawab atas belajarnya sendiri dan berusaha menemukan informasi untuk menjawab pertanyaan-pertanyaan yang diberikan pada mereka.

Dari uraian-uraian di atas dapat disimpulkan strategi pembelajaran kooperatif (cooperative learning) adalah pembelajaran yang mengutamakan adanya kelompokkelompok kecil atau tim yang bekerjasama menyelesaikan permasalahan dan menemukan ilmu pengetahuan yang spesifik. Dalam proses pembelajaran kooperatif siswa dituntut untuk bekerja sama dan bertanggung jawab untuk menyelesaikan tugas yang diberikan oleh guru, dengan memaksimalkan kondisi belajar dalam mencapai tujuan belajar.

Menurut Isjoni (2009:16) pembelajaran kooperatif memiliki ciri-ciri sebagai berikut: (1) Setiap anggota memiliki peran, (2) terjadi hubungan interaksi langsung diantara siswa, (3) setiap anggota kelompok bertanggung jawab atas belajarnya dan juga teman-teman sekelompoknya, (4) guru membantu mengembangkan keterampilan-keterampilan interpersonal kelompok, dan (5) guru hanya berinteraksi dengan kelompok saat diperlukan.

Menurut Rusman (2011:2013) strategi pembelajaran kooperatif mempunyai 6 type di dalamnya yaitu; (1) Student Teams Achievement Division (STAD), (2) Jigsaw, (3) Group Investigation (Investigasi kelompok), (4) Make a Match (Membuat Pasangan), (5) Teams
Games Tournaments (TGT) dan (6) Structural Approach. Kajian penelitian ini memfokuskan pada strategi pembelajaran kooperatif tipe STAD dan strategi pembelajaran ekspositori.

STAD dikembangkan Robert Slavin, dimana STAD merupakan pendekatan kooperatif yang sederhana. Strategi pembelajaran koperatif tipe STAD merupakan pendekatan cooperative learning yang menekankan pada aktivitas dan interaksi diantara siswa untuk saling memotivasi dan saling membantu dalam menguasai materi pelajaran guna mencapai prestasi yang maksimal.Guru yang menggunakan STAD mengacu pada pembelajaran kelompok, menyajikan informasi akademik baru pada siswa dengan menggunakan presentase verbal/teks. Anggota tim menggunakan lembar kegiatan/ perangkat pembelajaran yang lain untuk memahami bahan pelajaran melalui tutorial, kuis satu sama lain dan melakukan diskusi. Oleh karena itu, untuk mencapai tujuan kelompok setiap anggota kelompok harus membantu teman kelompoknya yang dapat mendorong kelompok itu mencapai tujuannya, sehingga siswa dapat terlibat secara aktif dalam pembelajaran dan dapat berdampak pada kualitas interaksi dan komunikasi antar siswa.

Strategi pembelajaran kooperatif tipe STAD dilaksanakan dengan beberapa tahap menurut (Slavin, 1995:153) yakni : (1) Menyampaikan Tujuan Pembelajaran dan Membangkitkan motivasi. (2) Menyajikan materi ajar. (3) Mengorganisasikan siswa dalam kelompok belajar. (4) Mengelola dan membantu kerja kelompok. (5) Tahap tes individu (kuis), siswa diberi kuis dengan tujuan mengetahui sejauh mana keberhasilan belajar yang telah dicapai siswa. (6) Tahap perhitungan skor perkembangan individu, skor ini dihitung berdasarkan skor awal.

Perilaku mengajar dengan strategi pembelajaran ekspositori merupakan kegiatan mengajar yang terpusat pada guru. Guru aktif memberikan penjelasan atau informasi terperinci tentang bahan pengajaran. Sedangkan Sanjaya (2009: 179) berpendapat strategi pembelajaran ekspositori adalah strategi pembelajaran yang menekankan kepada proses penyampaian materi secara verbal dari seorang guru kepada sekelompok siswa dengan maksud agar siswa dapat menguasai materi pelajaran secara optimal. Roy Killen (dalam Wina Sanjaya, 2009:179) menamakan strategi pembelajaran ekspositori ini dengan istilah 
pembelajaran langsung karena materi pembelajaran disampaikan langsung oleh guru, siswa tidak dituntut untuk menemukan materi dan merupakan bentuk dari pendekatan pembelajaran yang berorientasi kepada guru (teacher centered approach).

Menurut Sanjaya (2009:179) terdapat karakteristik strategi ekspositori sebagai berikut: 1) strategi ekspositori dilakukan dengan cara menyampaikan materi pelajaran secara verbal, artinya bertutur secara lisan merupakan alat utama dalam melakukan strategi ini, maka sering juga dinamakan istilah chalk and talk atau yang sering kita kenal dengan ceramah. 2) biasanya materi pelajaran yang disampaikan adalah materi pelajaran yang sudah jadi, seperti data, fakta, konsep-konsep tertentu yang harus dihapal sehingga tidak menuntut siswa untuk berpikir ulang. 3) tujuan utama pembelajaran adalah penguasaan materi itu sendiri, artinya setelah proses pembelajaran berakhir siswa diharapkan dapat memahaminya dengan benar dengan cara dapat mengungkapkan kembali materi yang telah diuraikan.

Anthony Gregore, profesor dibidang kurikulum dan pengajaran di Universitas Connecticut mengembangkan dua gaya berpikir pada manusia, yaitu : gaya berpikir sekuensial dan gaya berpikir acak. Kajian investigasinya menyimpulkan adanya dua kemungkinan dominasi otak ; persespsi konkrit dan abstrak serta kemampuan pengaturan secara sekuensial (linier) dan acak (non linier) (DePorter dan Hernacki , 2011:126).

Kemudian Gregore membagi lagi jenis gaya berpikir sekuensial menjadi dua bagian yaitu, sekuensial abstrak dan sekuensial konkrit. Masing-masing jenis gaya berpikir ini mempunyai karakteristik tertentu. Orang yang memiliki gaya berpikir sekuensial abstrak cenderung memiliki pola pikir logis, rasional dan intelektual. Orang ini cenderung menggunakan konsep dalam menyelesaikan suatu masalah dan selalu menganalisis informasi yang diterimanya. Realitas bagi orang dengan gaya berpikir sekuensial abstrak adalah dunia teori metafisis dan pemikiran abstrak.

Orang yang bertipe sekuensial konkrit ini cenderung berpegang pada kenyataan. Informasi diproses dengan cara teratur (tahap demi tahap), terurut dan linier. Bagi orang yang bertipe sekuensial konkrit ini, realitas terdiri dari apa yang dapat mereka ketahui melalui indra fisik mereka, yaitu indera penglihatan, pendengaran, peraba, penciuman, dan perasa. (DePorter dan Hernacki , 2011:128).

Catatan bagi para individu bertipe sekuensial konkrit adalah cara baik untuk meningkatkan hasil belajar. Siswa dengan gaya berpikir ini harus mengatur tugas-tugasnya menjadi proses tahap demi tahap dan berusaha keras untuk mendapatkan kesempurnaan pada setiap tahapnya. Selain itu, siswa bertipe sekuensial konkrit lebih menyukai pengarahan dan prosedur khusus. Orang seperti ini, dalam memperhatikan dan mengingat realitas dengan asosiasi visual secara teliti dan detail. Orang dengan pemikir sekuensial konkrit mempunyai masalah untuk mengingat instruksi secara verbal kecuali jika ditulis, dan sering sekali meminta bantuan orang lain untuk mengulanginya.

Strategi pembelajaran adalah keseluruhan kegiatan dan prosedur yang menitikberatkan pada kegiatan siswa dalam proses pembelajaran untuk mencapai tujuan tertentu. Strategi pembelajaran merupakan faktor eksternal yang dapat mendukung proses internal dalam belajar, seperti mengalihkan perhatian, memberi motivasi, memberi bimbingan,menilai hasil karya siswa dan member umpan balik. Gaya berpikir adalah salah satu faktor internal yang dapat mendorong keberhasilannya dalam menyelesaikan suatu persoalan.

Keterkaitan antara strategi pembelajaran dan cara berpikir siswa dalam situasi pembelajaran adalah hal yag sangat perlu diperhatikan. Sebagaimana yang dikemukakan para ahli di bidang pendidikan bahwa untuk meningkatkan hasil belajar maka strategi pembelajaran harus disesuaikan dengan karakteristik siswa.

Siswa yang memiliki gaya berpikir sekuensial abstrak yang cenderung dalam berpikir menggunakan konsep, memiliki pola pikir logis, rasional dan intelektual, lebih suka belajar sendiri, mampu melihat adanya informasi yang saling berhubungan dengan benar, dapat menarik kesimpulan untuk memberi jawaban atas permasalahanpermasalahan berdasarkan fakta, konsep dan teori-teori yang mendukung lebih efektif diajar dengan menggunakan strategi pembelajaran kooperatif STAD untuk meningkatkan hasil belajarnya, sebab dengan strategi ini proses pembelajaran berpusat pada siswa sehingga siswa dapat membangun sendiri pengetahuannya secara berkelompok dan lebih luas. 
Sebaliknya jika siswa yang memiliki gaya berpikir sekuensial abstrak diajar dengan strategi ekspositori cenderung hasil belajarnya rendah. Hal ini disebabkan karena pembelajaran ini berpusat pada guru, dimana guru lebih dominan dalam proses pembelajaran sehingga keinginan siswa untuk mengkonstruksi pengetahuannya terhambat atau siswa tidak lagi memiliki peranan dalam mengembangakan gaya berpikirnya.Dan akhirnya dapat menyebabkan kemajuan siswa dalam belajar untuk mengetahui sebab-sebab dari suatu persoalan dengan kemampuan yang ada pada dirinya tidak terealisasi dengan baik, sehingga timbul rasa kejenuhan dan kebosanan dalam belajar.

Sementara itu siswa yang memiliki gaya berpikir sekuensial konkret, dimana siswa ini memiliki pola pikir yang teratur dan spesifik, suka menyelesaikan satu permasalahan secara bertahap dan memerlukan prosedur lengkap yang diberikan oleh orang lain untuk menemukan konsep baru dalam belajar bila diajar dengan strategi pembelajaran kooperatif STAD kurang efektif dan dapat diduga akan terdapat perbedaan hasil belajar jika siswa yang memiliki gaya berpikir sekuensial konkret diajar dengan menggunakan strategi pembelajaran ekspositori. Sebab strategi pembelajaran kooperatif STAD, proses pembelajarannya lebih berpusat pada siswa dalam hal menemukan konsep baru dalam memecahkan masalah, guru berfungsi sebagai pemotivasi atau sebagai pembimbing saja. Sedangakan pada strategi pembelajaran ekspositori proses pembelajaran lebih berpusat pada orang lain atau guru, dimana guru merupakan sumber satu-satunya sumber untuk menyusun prosedur dan mengembangkan pelajaran untuk memperoleh konsep baru. Maka strategi ekspositori akan lebih efektif digunakan pada siswa yang memiliki gaya berpikir sekuensial konkret.

Berdasarkan uraian diatas dapat diduga, terdapat interaksi antara strategi pembelajaran dan gaya berpikir siswa terhadap hasil belajar siswa dalam mata pelajaran matematika.

\section{METODE}

Metode penelitian ini menggunakan metode eksperimen semu dengan melakukan eksperimen di dalam kelas yang sudah tersedia sebagaimana adanya, tanpa melakukan perubahan situasi kelas dan jadwal pembelajaran. Penelitian dilaksanakan pada pembelajaran pendidikan matematika dengan membandingkan antara strategi pembelajaran kooperatif STAD dengan strategi pembelajaran ekspositori dan dilaksanakan pada kelas yang telah ditetapkan. Kelas XI Tehnik Sepeda motor (TSM) - A melaksanakan strategi pembelajaran kooperatif STAD, sedangkan di kelas XI Tehnik Kenderaan Ringan (TKR)-A strategi ekspositori. Selanjutnya pada masing-masing kelas diberikan soal tes untuk mengetahui hasil belajar siswa. Dan tes gaya berpikir dilakukan sebelum perlakuan untuk mengetahui gaya berpikir yang dimiliki siswa. Gaya berpikir siswa dikategorikan atas gaya berpikir sekuensial abstrak dan gaya berpikir sekuensial konkrit.

Dalam penelitian ini desain yang digunakan yaitu faktorial $2 \times 2$. Melalui desain ini akan dibandingkan pengaruh antara strategi pembelajaran kooperatif STAD dan strategi ekspositori sebagai variabel bebas, gaya berpikir sekuensial abstrak dan sekuensial konkrit sebagai variabel moderator, dan hasil belajar dalam mata pelajaran matematika sebagai variabel terikat. Adapun desain penelitian ini dapat dijabarkan seperti Tabel di bawah ini.

Tabel 1. Desain Penelitian Untuk Pengujian Hipotesis

\begin{tabular}{|l|l|l|}
\hline $\begin{array}{l}\text { Strategi } \\
\text { Pembelajaran } \\
(\mathrm{A})\end{array}$ & $\begin{array}{l}\text { Kooperatif } \\
\text { STAD }\left(\mathrm{A}_{1}\right)\end{array}$ & $\begin{array}{l}\text { Ekspositori } \\
\left(\mathrm{A}_{2}\right)\end{array}$ \\
$\begin{array}{l}\text { Gaya Berpikix } \\
(\mathrm{B})\end{array}$ & $\mathrm{A}_{1} \mathrm{~B}_{1}$ & $\mathrm{~A}_{2} \mathrm{~B}_{1}$ \\
\hline $\begin{array}{l}\text { Sekuensial } \\
\text { Abstrak } \\
\left(\mathrm{B}_{1}\right)\end{array}$ & $\mathrm{A}_{1} \mathrm{~B}_{2}$ & $\mathrm{~A}_{2} \mathrm{~B}_{2}$ \\
\hline $\begin{array}{l}\text { Sekuensial } \\
\text { Konkrit } \\
\left(\mathrm{B}_{2}\right)\end{array}$ & \\
\hline
\end{tabular}

Keterangan :

$\mathrm{A}_{1} \mathrm{~B}_{1}=$ Hasil belajar siswa yang diajar dengan strategi pembelajaran kooperatif STAD memiliki gaya berpikir sekuensial abstrak

$\mathrm{A}_{1} \mathrm{~B}_{2}=$ Hasil belajar siswa yang diajar dengan strategi pembelajaran kooperatif STAD yang memiliki gaya berpikir sekuensial konkrit

$\mathrm{A}_{2} \mathrm{~B}_{1}=$ Hasil belajar siswa yang diajar dengan strategi pembelajaran 
ekspositori yang memiliki gaya berpikir sekuensial abstrak

$\mathrm{A}_{2} \mathrm{~B}_{2}=$ Hasil belajar siswa yang diajar dengan strategi pembelajaran ekspositori yang memiliki gaya berpikir sekuensial konkrit.

\section{HASIL DAN PEMBAHASAN \\ Hasil \\ Deskripsi Data Hasil Penelitian}

Data-data hasil temuan penelitian dikelompok berdasarkan interaksi antara strategi pembelajaran kooperatif STAD dengan gaya berpikir sekuensial siswa.

Pengujian hipotesis dilakukan menggunakan teknik analisis varians (anava) dua jalur dengan desain faktorial $2 \times 2$. Hasil perhitungan analisis varians dua jalur, secara ringkas dirangkum pada Tabel di bawah ini.

Tabel 2. Rangkuman Hasil Pengujian Analisis Varians Dua Jalur

\begin{tabular}{|l|l|r|r|r|l|}
\hline Sumber Variasi & dk & \multicolumn{1}{l|}{$\mathrm{JK}$} & $\mathrm{RK}=\mathrm{JK} / \mathrm{dk}$ & \multicolumn{1}{l|}{ Fh } & Ft $\alpha=0,05$ \\
\hline Antar Kolom (A) & 1 & 38,521 & 36,521 & 13,68 & 4,06 \\
Antar Baris (B) & 1 & 56,884 & 56,884 & 20,19 & 4,06 \\
Interaksi (AB) & 1 & 28,507 & 28,507 & 10,12 & 4,06 \\
Dalam & 44 & 123,913 & 2,816 & & \\
\hline Total Direduksi & 47 & 301,67 & - & & \\
\hline
\end{tabular}

a. Siswa yang Diajar dengan Strategi Pembelajaran Kooperatif STAD $\left(\mathrm{A}_{1}\right)$ Memperoleh Hasil Belajar Matematika yang Lebih Tinggi Dibandingkan Siswa yang Diajar dengan Strategi Pembelajaran Ekspositori $\left(\mathrm{A}_{2}\right)$ adalah:

Adapun hipotesis statistik, yang diuji

$\mathrm{H}_{\mathrm{o}}: \mu \mathrm{A}_{1}=\mu \mathrm{A}_{2}$

$\mathrm{H}_{\mathrm{a}}: \mu \mathrm{A}_{1}>\mu \mathrm{A}_{2}$

Berdasarkan hasil penelitian diperoleh rata-rata hasil belajar matematika kelompok siswa yang diajar dengan strategi pembelajaran kooperatif STAD sebesar 28,21 dan hasil belajar matematika kelompok siswa yang diajar dengan strategi pembelajaran eskpositori diperoleh rata-rata sebesar 26,50.

Hasil analisis pada Tabel untuk hipotesis pertama (antar kolom) diperoleh nilai $F_{\text {hitung }}$ sebesar 13,678. Pada taraf signifikansi $\alpha$ $=0,05$ diperoleh $\mathrm{F}_{0,05(1 ; 44)}=4,06$. Karena nilai $\mathrm{F}_{\text {hitung }}>\mathrm{F}_{\text {tabel }}$ yaitu 13,678> 4,06 maka untuk uji hipotesis pertama ditolak $\mathrm{H}_{\mathrm{o}}$ dan terima $\mathrm{H}_{\mathrm{a}}$ sehingga disimpulkan hasil belajar matematika siswa yang diajar dengan strategi pembelajaran kooperatif STAD lebih tinggi dari pada hasil belajar siswa yang diajar dengan strategi pembelajaran ekspositori teruji kebenarannya.

b. Siswa yang Memiliki Gaya Berpikir Sekuensial Abstrak Memperoleh Hasil Belajar Matematika yang Lebih Tinggi Dibandingkan dengan Siswa yang Memiliki Gaya Berpikir Sekuensial Konkret adalah:

Adapun hipotesis statistik, yang diuji

$$
\begin{aligned}
& \mathrm{H}_{\mathrm{o}}: \mu \mathrm{B}_{1}=\mu \mathrm{B}_{2} \\
& \mathrm{H}_{\mathrm{a}}: \mu \mathrm{B}_{1}>\mu \mathrm{B}_{2}
\end{aligned}
$$

Berdasarkan hasil temuan penelitian diperoleh rata-rata hasil belajar matematika kelompok siswa yang memiliki gaya berpikir sekuensial abstrak sebesar 28,36 dan kelompok siswa yang memiliki gaya berpikir sekuensial konkret diperoleh rata-rata hasil belajar sebesar 26,24 .

Hasil analisis pada lampiran, untuk hipotesis kedua (antar baris) diperoleh nilai $F_{\text {hitung }}>F_{\text {tabel }}$ yaitu 20,19 $>$ 4,06 maka tolak $\mathrm{H}_{\mathrm{o}}$ dan terima $\mathrm{H}_{\mathrm{a}}$ sehingga disimpulkan bahwa hasil belajar matematika siswa yang memiliki gaya berpikir sekuensial abstrak lebih tinggi daripada hasil belajar matematika siswa yang memiliki gaya berpikir sekuensial konkret teruji kebenarannya.

c. Terdapat Interaksi Antara Strategi Pembelajaran dan Gaya Berpikir Sekuensial Siswa Terhadap Hasil Belajar matematika Adapun hipotesis statistik, yang diuji adalah:

$$
\begin{aligned}
& \mathrm{H}_{\mathrm{o}}: \mu \mathrm{A}><\mu \mathrm{B}=0 \\
& \mathrm{H}_{\mathrm{a}}: \mu \mathrm{A}><\mu \mathrm{B} \neq 0
\end{aligned}
$$

Berdasarkan hasil temuan penelitian diperoleh hasil belajar matematika kelompok siswa yang diajar dengan strategi pembelajaran kooperatif STAD dan memiliki gaya berpikir sekuensial abstrak rata-rata sebesar 30,46; kelompok siswa yang diajar dengan strategi 
pembelajaran kooperatif STAD dan memiliki gaya berpikir sekuensial konkret diperoleh ratarata sebesar 25,73; kelompok siswa yang diajar dengan strategi pembelajaran ekspositori dan memiliki gaya berpikir sekuensial abstrak diperoleh rata-rata nilai sebesar 26,25; sementara kelompok siswa yang diajar dengan strategi pembelajaran ekspositori dan memiliki gaya berpikir sekuensial konkret diperoleh ratarata nilai sebesar 26,75. Selanjutnya Pembahasan

1. Perbedaan Hasil Belajar Matematika Antara Siswa Yang Diajar Dengan Strategi Pembelajaran Kooperatif STAD Dan Siswa Yang Diajar Dengan Strategi Pembelajaran Ekspositori

Hasil temuan penelitian, diperoleh ratarata hasil belajar matematika siswa yang diajar dengan strategi pembelajaran kooperatif STAD sebesar 28,01 sedangkan nilai rata-rata hasil belajar matematika siswa yang diajar dengan strategi pembelajaran eskpositori sebesar 26,50. Hasil pengujian hipotesis diperoleh nilai $F_{\text {hitung }}$ $>\mathrm{F}_{\text {tabel }}$ yaitu 13,678 > 4,06 sehingga hipotesis pertama yang diajukan diterima dan disimpulkan bahwa hasil belajar matematika siswa yang diajar dengan strategi pembelajaran kooperatif STAD lebih tinggi dari pada hasil belajar siswa yang diajar dengan strategi pembelajaran ekspositori.

Strategi pembelajaran kooperatif STAD pada dasarnya merupakan teknik yang cukup bagus untuk lebih memahami isi pelajaran. Strategi pembelajaran kooperatif STAD dapat mendorong siswa sehingga aktif untuk terlibat secara fisik, emosi dan mental dalam kegiatan pembelajaran. Para siswa berusaha secara sendiri maupun kelompok mencari sumbersumber materi yang dapat menjelaskan konsep dan teori yang terdapat pada perumusan masalah sesuai konteks materi pembelajaran, sehingga siswa memiliki kebebasan untuk mengembangkan kemampuannya.

Penerapan strategi kooperatif STAD dapat membantu siswa mentransfer pengetahuan mereka untuk memahami masalah dalam kehidupan nyata. Pengetahuan yang diterima siswa akan lebih bermakna digunakan dalam kehidupan sehari-harinya, kebermaknaan ini dapat berarti bahwa siswa akan terus mengingat pengetahuan yang diterima. Siswa juga dapat terbantu dalam mengembangkan pengetahuan barunya dan bertanggung jawab dalam pembelajaran yang mereka lakukan. Dengan demikian proses pembelajaran strategi berdasarkan hasil analisis varians pada Lampiran 14 , diperoleh nilai $F_{\text {hitung }}>F_{\text {tabel }}$ yaitu 10,12> 4,06 sehingga tolak $\mathrm{H}_{\mathrm{o}}$ dan terima $\mathrm{H}_{\mathrm{a}}$ dan disimpulkan terdapat interaksi antara strategi pembelajaran dengan gaya berpikir sekuensial dalam mempengaruhi hasil belajar matematika siswa teruji kebenarannya.

kooperatif STAD memberikan pengalaman belajar yang dapat mendukung perubahan kebiasaan, kecakapan atau pengetahuan, sikap dan keterampilan sebagai wujud hasil belajar.

Sementara itu strategi pembelajaran ekspositori merupakan pembelajaran yang berpusat pada guru, siswa kurang diberdayakan dan komunikasi yang terjadi umumnya bersifat satu arah. Dalam proses pelekasanaan strategi pembelajaran ekspositori siswa hanya dapat menyelesaikan masalah sesuai dengan cara yang ditunjukkan guru, hingga membuat siswa bersifat menunggu penjelasan atau intruksi dari guru. Hal ini dapat member pengaruh terhadap perolehan hasil belajar dan pandangan siswa sehingga menimbulkan sikap-sikap tertentu seperti : kurang peka dan peduli terhadap materi yang disampaikan, selalu mengharap jawaban dari guru, dan tidak berusaha mencari sumbersumber lain yang berkenaan dengan materi pelajaran. Akibatnya hasil belajar yang diperoleh siswa dengan menggunakan strategi ini umumnya tidak bertahan lama dalam struktur kognitif siswa.

Berdasarkan hasil dan temuan-temuan penelitian yang diperoleh, maka dapat diindikasikan bahwa strategi pembelajaran kooperatif STAD memberikan pengaruh yang lebih baik dalam meningkatkan hasil belajar matematika siswa dibandingkan strategi pembelajaran ekspositori.

\section{Perbedaan Hasil Belajar Siswa yang} Memiliki Gaya Berpikir Sekuensial Abstrak dengan Siswa yang Memiliki Gaya Berpikir Sekuensial Konkret

Hasil tabulasi dan temuan penelitian diperoleh rata-rata hasil belajar matematika siswa yang memiliki gaya berpikir sekuensial abstrak (baik yang diajar dengan strategi pembelajaran kooperatif STAD maupun yang diajar dengan strategi pembelajaran ekspositori) sebesar 38,36. Sedangkan rata-rata hasil belajar matematika siswa yang memiliki gaya berpikir sekuensial konkret (baik yang diajar dengan 
strategi pembelajaran kooperatif STAD maupun yang diajar dengan strategi pembelajaran ekspositori) sebesar 26,24. Hasil pengujian hipotesis diperoleh nilai $\mathrm{F}_{\text {hitung }}>\mathrm{F}_{\text {tabel }}$ yaitu 20,19 > 4,06 sehingga hipotesis kedua yang diajukan diterima dan disimpulkan bahwa hasil belajar matematika siswa yang memiliki gaya berpikir sekuensial abstrak lebih tinggi daripada hasil belajar matematika siswa yang memiliki gaya berpikir sekuensial konkret.

Pada pembelajaran matematika diperlukan suatu model pemikiran sebuah konsep yang logis, rasional, kritis, cermat dan efektif serta efisien. Sesuai dengan hal ini gaya berpikir siswa adalah merupakan indikator yang perlu diperhatikan agar hasil belajarnya lebih baik. Hal tersebut dapat menjadi pertimbangan pada penentuan strategi pembelajaran yang digunakan. Gaya berpikir sekuensial abstrak merupakan suatu model berpikir yang menggunakan konsep dalam menganalisis suatu informasi bersifat logis, rasional dan intelektual. Siswa yang memiliki gaya berpikir seperti ini lebih suka bekerja sendiri dan selalu ingin mengetahui sebab-sebab suatu persoalan.Kemampuan untuk menanggapi suatu permasalahan bagi siswa yang memiliki gaya berpikir sekuensial abstrak tampak lebih unggul dibandingkan dengan siswa yang memiliki gaya berpikir sekuensial konkret.Siswa yang memiliki gaya berpikir sekuensial abstrak dalam mengelola informasi cenderung menggunakan peranan akal yang lebih dominandisamping penguasaan atas prinsip, konsep dan generalisasi ataupun pengorganisasian. Hal ini sangat sesuai dengan pendapat dari Muhibbin (2004) yang menyatakan bahwa pemikir sekuensial abstrak dalam mengolah informasi cenderung menggunakan peranan akal yang kuat (logika) disamping penguasaan prinsip, konsep dan generalisasi.

Sedangkan siswa yang memiliki gaya berpikir sekuensial konkret cenderung pola pikirnya atas dasar realitas. Mereka menggunakan indera fisik untuk membuktikan kebenaran suatu informasi, memiliki pola pikir teratur dan spesifik, suka bekerja dengan menggunakan bantuan dan arahan dari orang lain. Mereka selalu berusaha mendapatkan kesempurnaan dari pekerjaan mereka tahap demi tahap. Hal ini sangat didukung oleh pandangan DePorter (2011)yang menyatakan bahwa pemikir sekuensial konkret dalam menerima informasi cenderung membutuhkan penjelasan dan tujuan yang menyeluruh dari suatu permasalahan.

Berdasarkan hasil temuan penelitian yang ada, maka memberi indikasi bahwa gaya berpikir sekuensial siswa berpengaruh terhadap hasil belajar matematika yang dicapai siswa. Dengan demikian, dari hasil penelitian yang telah dilakukan diperoleh bahwa hasil belajar matematika siswa yang memiliki gaya berpikir sekuensial abstrak lebih tinggi dibandingkan kelompok siswa yang memiliki gaya berpikir sekuensial konkret.

3. Interaksi Antara Strategi Pembelajaran dan Gaya Berpikir Sekuensial Siswa Terhadap Hasil Belajar Matematika.

Hasil pengelompokkan data diperoleh rata-rata hasil belajar matematika kelompok siswa memiliki gaya berpikir sekuensial abstrak diajar dengan strategi pembelajaran kooperatif STAD sebesar 30,46; kelompok siswa yang memiliki gaya berpikir sekuensial konkret diajar dengan strategi pembelajaran kooperatif STAD diperoleh rata-rata hasil belajar sebesar 25,73; kelompok siswa yang memiliki gaya berpikir sekuensial abstrak diajar dengan strategi pembelajaran ekspositori diperoleh ratarata hasil belajar sebesar 26,25; sedangkan kelompok siswa yang memiliki gaya berpikir sekuensial konkret diajar dengan strategi pembelajaran ekspositori diperoleh rata-rata hasil belajar sebesar 26,75.

Hasil pengujian hipotesis ketiga menggunakan uji analisis varians dua jalur diperoleh $\mathrm{F}_{\text {hitung }}>\mathrm{F}_{\text {tabel }}$ yaitu $10,123>4,06$ sehingga hipotesis ketiga yang diajukan diterima yang berarti terdapat interaksi antara strategi pembelajaran dengan gaya berpikir sekuensial dalam mempengaruhi hasil belajar matematika siswa.

Strategi pembelajaran merupakan metode dan prosedur yang menitik-beratkan pada kegiatan siswa dalam proses pembelajaran untuk mencapai tujuan tertentu. Strategi pembelajaran merupakan faktor eksternal yang dapat mendukung proses internal dalam belajar, seperti mengalihkan perhatian, memberi motivasi, memberi bimbingan, menilai hasil karya dan memberikan umpan balik. Sedangkan gaya berpikir adalah salah satu faktor internal yang dapat mendorong keberhasilannya dalam menyelesaikan suatu persoalan. Keterkaitan antara pembelajaran dan gaya berpikir siswa dalam situasi pembelajaran merupakan hal yang sangat perlu diperhatikan. 
Strategi pembelajaran kooperatif STAD merupakan suatu strategi yang menggunakan tahapan pembelajaran yang mengaktifkan siswa dengan mengikutsertakan secara langsung siswa dalam bentuk diskusi dan kerjasama dalam tim. Dalam strategi pembelajaran ini, diperlukan wawasan dari siswa dalam mencari pemecahan masalah yang berhubungan dengan kegiatan yang dipelajari dan menghubungkannya dengan konsep-konsep yang ada pada materi pelajaran. Siswa yang memiliki gaya berpikir sekuensial abstrak yang cenderung dalam berpikir menggunakan konsep, memiliki pola berpikir yang logis, rasional dan intelektual, lebih suka belajar sendiri, mampu melihat adanya informasi yang saling berhubungan dengan benar, dapat melakukan analisis dengan metode deduktif, serta dapat menarik kesimpulan untuk memberi jawaban atas permasalahanpermasalahan berdasarkan fakta, konsep dan teori-teori yang mendukung sehingga diduga akan lebih efektif di ajar dengan menggunakan strategi pembelajaran kooperatif STAD untuk meningkatkan prestasi belajarnya. sebab startegi ini proses pembelajarannya sangat berpusat pada siswa dalam menemukan jawaban dari suatu permasalahan dalam pelajaran dan menekankan pada langkahlangkah berpikir yang dimulai dari menyadari kesenjangan, merumuskan masalah, membuat hipotesis dan mengumpulkan data serta menarik kesimpulan untuk mencapai pada penyelesaian masalah.

Sebaliknya jika siswa memiliki gaya berpikir abstrak diajar dengan strategi pembelajaran ekspositori diduga prestasinya akan lebih rendah, sebab metode ini didominasi oleh guru, sehingga siswa yang memiliki gaya berpikir abstrak untuk mengetahui sebab-sebab dari suatu persoalan dengan gaya yang ada pada dirinya tidak terealisasikan dengan baik, sehingga timbul rasa kejenuhan dalam belajar yang mengakibatkan prestasi belajarnya rendah.

Sementara itu siswa yang memiliki gaya berpikir sekuensial konkret, yaitu siswa yang memiliki pola pikir teratur dan spesifik, suka menyelesaikan suatu permasalahan secara tahap demi tahap dan memiliki prosedur lengkap yang diberikan oleh orang lain untuk menemukan suatu konsep baru dalam belajar bila diajar dengan menggunakan strategi pembelajaran kooperatif STAD kurang meningkatkan hasil belajarnya. Sebab strategi ini lebih berpusat pada siswa, guru hanya sebagai pemotivator atau pembimbing. Dengan demikian siswa yang memiliki kemampauan berpikir sekuensial konkret kurang mampu menyelesaikan persoalan-persoalan atau dengan kata lain kurang dapat menyelesaikan permasalahan dengan baik. Bagi siswa yang memiliki gaya berpikir sekuensial konkrit dalam proses pembelajaran, strategi pembelajaran ekspositori akan lebih efektif digunakan untuk meningkatkan prestasi belajarnya. sebab langkah-langkah yang digunakan dalam strategi pembelajaran ekspositori sesuai dengan karakteristik siswa yang memiliki gaya berpikir sekuensial konkrit yaitu memiliki pola pikir yang teratur, cenderung menyelesaikan permasalahan tahap demi tahap dan memerlukan prosedur yang lengkap serta memerlukan penjelasan dari orang lain.

Berdasarkan rata-rata hasil belajar yang diperoleh siswa memberi indikasi bahwa kelompok siswa yang memiliki gaya berpikir sekuensial abstrak akan memperoleh hasil belajar yang lebih baik jika diajar dengan strategi pembelajaran kooperatif STAD dibandingkan strategi pembelajaran ekspositori. Sebaliknya kelompok siswa yang memiliki gaya berpikir sekuensial konkret akan memperoleh hasil belajar yang lebih baik jika diajar dengan strategi pembelajaran ekspositori dibandingkan strategi pembelajaran kooperatif STAD. Dengan demikian, dari hasil temuan penelitian dan pengujian hipotesis terbukti bahwa ada pengaruh strategi pembelajaran dan gaya berpikir sekuensial terhadap hasil belajar matematika siswa baik secara terpisah maupun secara interaksi atau bersamaan.

\section{PENUTUP}

Hasil-hasil temuan penelitian dan analisis yang telah dilakukan, diperoleh beberapa simpulan, antara lain: (1) Hasil belajar matematika siswa yang diajar dengan strategi pembelajaran kooperatif STAD lebih tinggi daripada hasil belajar siswa yang diajar dengan strategi pembelajaran ekspositori.(2) Hasil belajar matematika siswa yang memiliki gaya berpikir sekuensial abstrak lebih tinggi daripada hasil belajar matematika siswa yang memiliki gaya berpikir sekuensial konkret. (3) Terdapat interaksi antara strategi pembelajaran dengan gaya berpikir sekuensial dalam mempengaruhi hasil belajar matematika siswa. Berdasarkan nilai rata-rata yang diperoleh siswa 
memberi indikasi bahwa kelompok siswa yang memiliki gaya berpikir sekuensial abstrak lebih tepat jika diajar dengan strategi pembelajaran kooperatif STAD. Sebaliknya kelompok siswa yang memiliki gaya berpikir sekuensial konkret lebih tepat jika diajar dengan strategi pembelajaran ekspositori.

\section{DAFTAR PUSTAKA}

Arikunto, S. (2009). Dasar-dasar Evaluasi Pendidikan. Jakarta: Bumi Aksara.

Bloom, Benyamin S, (1986), Taxonomy of Education Objective, New York: Longman.

DePorter dan Hernacki . (2011). Quantum Learning (penerjemah: Alwyah Abdurrahman), Bandung: Kaifa

Dick, W dan Carey, L. (2005). The Sistematic Design Of Instruction. Fourth edition, Harper Collins

Gage, N. L \& David, C. Berliner. (1998). Educational psychology (sixth edition).New York: Houghton Miffin Company.

Hudojo, H.(1998). Mengajar Belajar Matematika, Jakarta, Depdikbud.

Isjoni. (2009). Cooperatif Learning. Bandung : Alfa Beta.
Muhibbin Syah, (2004). Psikologi Pendidikan dengan Pendekatan Baru. Bandung : Remaja Rosda Karya

Rusman. (2011). Model-Model Pembelajaran. Jakarta: PT Rajagrafindo Persada.

Sanjaya, W. (2009). Kurikulum dan Pembelajaran. Teori dan praktik pengembangan Kurikulum Tingkat Satuan Pendidikan (KTSP), Jakarta : Kencana Prenada Media Group.

Sanjaya, W. (2009). Strategì Pembelajaran Berorientasi Standar Proses Pendidikan,Jakarta : Kencana Prenada Media Group.

Savage V. Tom \& Amstrong DG. (1987). Effective Teaching in Sosial Studies. Third Edition. New Jersey: Prentice Hall.

Slavin, R.E.(1995). Cooperatif Learning: Theory, Research and Practice $\left(2^{\text {rd }}\right)$ Boston: Allyn and Bacon Publiser.

Wena, M. (2009). Strategi Pembelajaran Inovatif kontemporer suatu Tinjauan konseptual Operasional, Jakarta: Bumi Aksara

Wina Sanjaya. (2009). Penelitian Tindakan Kelas. Jakarta : Kencana.

Winkel, W. S. (1991). Psikologi pengajaran, Jakarta : Grasindo 